\title{
Learning Fractions through Swimming Context for Elementary School Students
}

\author{
Meta Silvia Gunawan, Ratu Ilma Indra Putri*, Zulkardi \\ Universitas Sriwijaya \\ Palembang, Indonesia \\ ratu.ilma@yahoo.com
}

\begin{abstract}
This research aimed to produce learning trajectory by using the swimming context in helping students to understand the concept of fractions and addition of fractions. The approach used was Realistic Mathematics Education, Indonesian version (PMRI). The study involved 6 fourth grade students with heterogeneous capabilities in Elementary School IBA, South Sumatra, Indonesia. The method used was a design research with three phases of the preliminary design, the design experiment, and retrospective analysis. However, this study only shows the results at the phase of the design experiment, in particular on a pilot experiment. Data collection techniques used were video recordings, photograph, the student's work, the results of pretest and posttest, and student interview during learning. The results showed that the swimming context could stimulate students' informal knowledge of the meaning of fractions in which it can eventually be used in addition of fractions material.
\end{abstract}

Keywords-Addition of Fractions, Design Research, PMRI, the swimming context

\section{INTRODUCTION}

Learning fractions in Indonesia tend to focus on procedures only. The problem is a variety of fractions meaning as one of the difficulty causes in the learning fractions [1]. The students should be given the widest possible opportunity to explore the meaning of fractions before students study the relationship between fractions and operations on fractions [2]. Another problem is the students' difficulties in adding fractions, especially with different denominators. The difficulty in conventional teaching causes hazy understanding of fractions itself. Thus, when teacher explains how to solve addition of fractions by equating the denominator, students follow mechanistically (without understanding).

Learning should be more meaningful so that students are more active and understanding of the subjects taught. Studentcentered learning system can be achieved if teachers can use a variety of flexible teaching strategies [3][4][5]. Therefore, it is necessary that a promising approach to be applied, that is Realistic Mathematic Education, in Indonesia (PMRI). PMRI is selected because it is in line with the 2013 Curriculum in which the objectives of the 2013 Curriculum is to provide knowledge to the students completely and not fragmented [6]. The 2013 Curriculum emphasizes the involvement of students to find the lesson concepts through teachers' role as a facilitator. However, even though the learning activities have been followed, the level of variety in the creativity of teachers remains low [5]. Therefore, teachers should be more creative in designing the learning in the classroom. PMRI provides opportunities for teachers and students to communicate well to create social interaction in the classroom. One of the advantages of PMRI is able to add the communication between teachers-students and students-students. Social interactions in the classroom occur when students work together in solving mathematical problems given and are able to explain the problems based on the socio-mathematics norms [6]. Social-mathematics norms, for instance, are shown by the students' agreement about the correct answer, and they contain not only a correct mathematical calculation, but also a correct understanding and interpretation of the teacher's questions [7], [8].

In PMRI, the teaching is built on informal knowledge of students, and it is important to give students the opportunity to explore some of the situations of daily lives where the fractions play a role [9]. PMRI is an approach that starts from the real things for students and emphasizes the skills of discussing process with classmates so that at last their discovery can be used to solve problems either individually or in groups [10]. The situation of students' lives is not only about the real extent of the students' views, but also all imagination of students, affordable by their imagination [9][11].

PMRI requires a context which is close to the students to help students in understanding the lesson [10]. There are four contexts in learning math, namely student personal aspect, academics, public society and scientific aspect [12][13][6].

The swimming context is chosen because it can represent fractions using measurements. The shape of the pool is one model that allows to represent parts of the whole. The measurement concerns the identification of a length which uses the length as a part in determining the length of an object [14].

Several previous studies have shown good results in learning fractions by using the PMRI approach, namely the research by [15] which showed that a series of activities have 
been done to help students in learning fractions. A study conducted by [16] showed that the results of the use of learning media of the fraction bar can support students' understanding in comprehending fractions from informal phase to formal phase. The teaching materials about addition of fraction using PMRI developed by [1] also revealed the good results in which the materials can extremely guide students to develop ideas and foster the creativity in solving problems.

To implement the study, the authors used design research method. It consists of three stages: preliminary design, experiment (a pilot experiment and teaching experiment), and retrospective analyze. But this current research was limited to the pilot phase of the experiment.

From the above discussion, the researchers conduct a research conduct with the aim of developing a theory of learning to assist students to understand the concept of the adding fractions using the swimming context.

\section{METHOD}

This research used design research as the method which was designing learning fractions material for the fourth grade students. Research design is a method of the research which aims to develop the Local Instructional Theory (LIT) to improve the quality [17]. In this research, the developed design was Hypothetical Learning Trajectory (HLT) which contained a series of students' learning activities. The research design consists of three phases, which are:

(1) Preliminary design. HLT have been designed which contained the anticipation of things that might happen. Before designing, the researchers determined the learning objectives or the objectives which would be achieved and the starting point of learning. HLT consists of three parts: learning objectives, learning activities, and hypotheses of learning process that will occur [18]. In the perspective of design research, the objective of the preliminary design was to formulate the local instructional theory (LIT) which can be elaborated and perfected while performing experiments [19],[20].

(2) The design of experiment (Pilot and teaching experiment). This pilot experiment is referred as a bridge between the preliminary phase and the teaching experiment phase. The purpose of this pilot experiment was to test the initial HLT. The main target of this phase was to collect the data to support the suitability with the initial HLT. This research was limited until this phase.

The purpose of experiment is to test and improve LIT which is developed at an early stage and to develop an understanding of how it works [19]. The experiment also aims to gather data to answer the research questions [20].

(3) Retrospective analysis. All of the data obtained in the experimental phase were analyzed. The data obtained from the learning activities in the classroom were analyzed and the analysis results were used to plan the activities or to develop the design on the next learning activities. The aim was to develop local instrument theory.
Pictures of the research design phase are shown in Fig. 1.

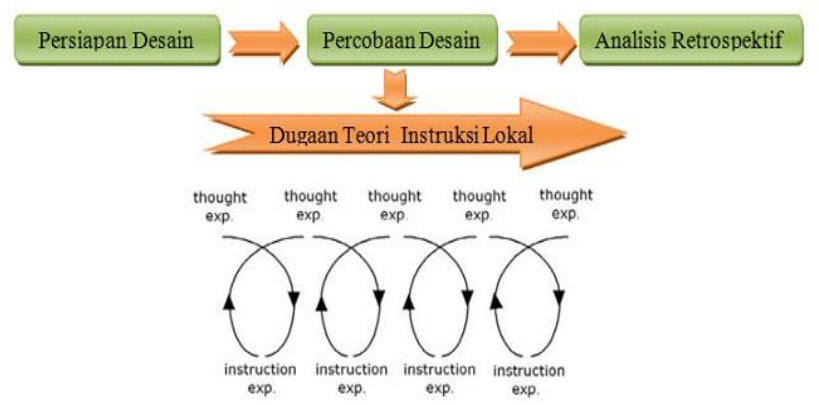

Fig. 1. Research desaign phase

This research involved 6 of $4^{\text {th }}$ grade students from Elementary School IBA Palembang whose ages ranging from 10-11 years. The techniques of data collection to answer the research problems, which were observation, interview and documentation.

The objective of the observation was to get an idea dealing with social norms of mathematics which prevails in the class, the teaching methods used, class organization, the rules in the classroom, the students' work and the time allocation during the learning process.

Interview was conducted on mathematics education experts, teachers and students. Interview to the experts aimed to determine the suitability between content and relevance, the application context, interoperability, and the ease of material, language which is easy to understand and the adequacy of time. The objective was to get in-depth information about the difficulties of teacher in teaching the material, the level of students' understanding, teacher's experience toward PMRI approach, and students' experience toward PMRI approach. The role of the researchers in this learning activities was to ask the students some addition questions, observe the learning activities, coordinate activities, and to make changes to activities which are required to provide relevant information on the research [21].

Documentation was done together with observations to see how the learning process occurs, the students' strategies and the students' thinking process from the informal stage to the formal stage in mathematics. Documentation data were collected through video recordings and photos.

The technique of data analysis was conducted qualitatively. The data which have been collected at the preliminary, pilot experiment, and teaching experiment phases were analyzed on the retrospective analysis phase. The results of the analysis of observation sheets, interview results and pretest results of pilot experiment phase were used as guidelines for designing the initial HLT. Besides analyzing the results of the students' written test, data analysis on the research design method was performed by comparing the observation results during the learning process with the designed HLT. 


\section{RESULTS AND DISCUSSION}

In the preliminary design phase, the researchers examined the literature of the instruments to be used in the research series. Obtained from the discussion were the design of hypothetical learning trajectory, student activity sheet, test questions, lesson plans, teacher's guides, and scoring guides. Once the researchers had designed the initial learning, the learning equipment that would be used were obtained. The learning activities are described as follows.

\section{A. Student activity 1. The meaning of fractions}

The problems given in activity 1 were associated with elements of fractions. At the beginning of the lesson, teacher gave apperception by asking "Did you ever swim?", "Tell us your story!", "How do you think swimmer can win the race?" Such activities made the students answer in enthusiasm.

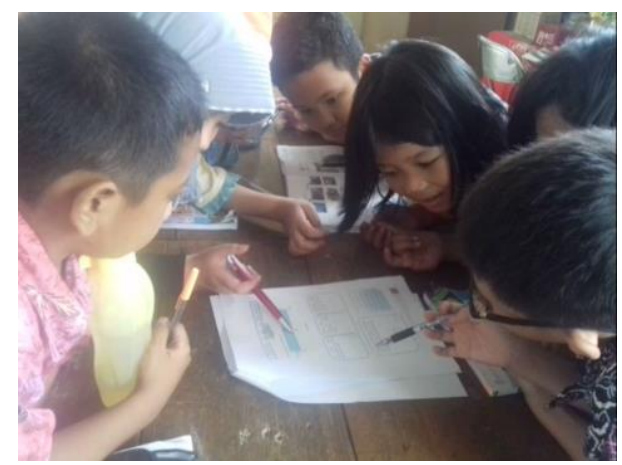

Fig. 2. Students' activity 1

The teacher then instructed the students to sit in groups and gave the activity sheet 1 . The students started working in groups. The students discussed and performed the activity, and the teacher as a facilitator observed student activities. After they were done with the discussion and the activity sheet 1 , the students presented their respective answers. Problems presented in the activity 1 form the part that has been pursued athletes when swimming. The first question asked the length of swimming pool. The second question asked the distance of the athletes. After that, the students determined which parts reached athlete. From the answers, students' understanding of the fraction meaning began to be built. Students can know that the part that has been taken by athletes is one of the meanings of fractions. At the end, the students concluded that the distance covered by the athletes is the numerator, while the length of the pool is the denominator of the fraction. A picture of student activity in discussion groups as well as drawing on the answers of students can be seen in Fig. 3.

In Figure 3, students made fractions of a given problem. The length of the pool is the denominator, and the distance reached by the athlete is the numerator. In an interview with the student, at the final conclusion the students were able to determine where the numerator and denominator were. So the purpose of this activity can be achieved.

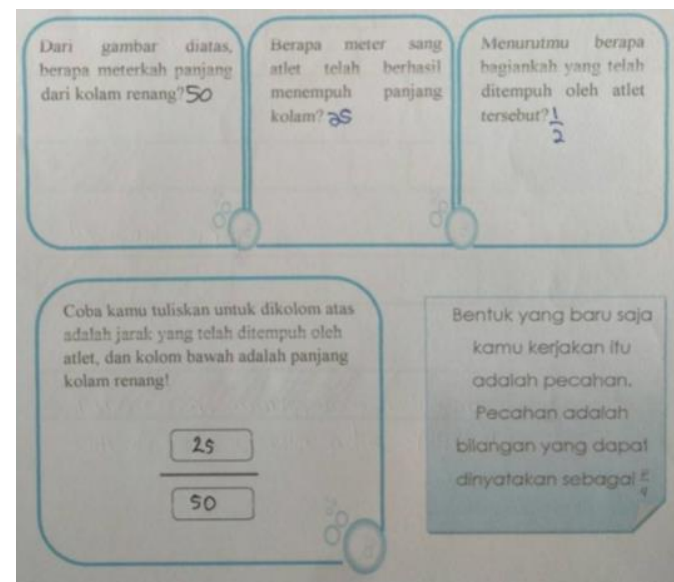

Fig. 3. Students' answers on the activity 1

\section{B. Student activity 2. Addition of fractions with same denominators}

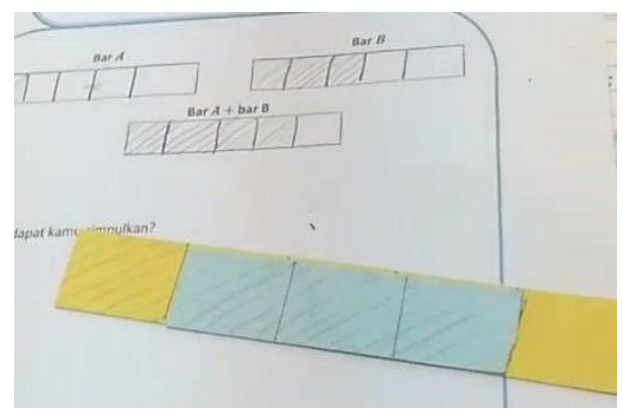

(a)

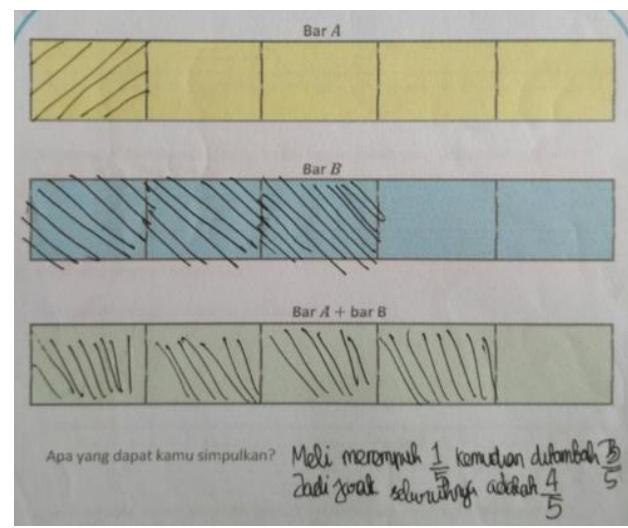

(b)

Fig. 4. Students' activity and students' answers on the activity $2 \mathrm{a}$ using fraction bar

The students were required to solve a problem where an athlete reached certain distances in certain seconds, and then the two distances were added up. In this activity, the students were asked to use the fraction bar in the process of finding the sum of the fractions. Student activity started from shading fraction bar according to the distance covered for 20 seconds, and then students shaded again another fraction bar according to the distance in 30 seconds. Furthermore, the students cut one bar in accordance with the shaded fraction, after the students 
pasted the shaded part which has been cut to the piece of top bar. From the bar, the students can determine the sum of the parts that have been taken by athletes. Students' answer can be seen in Fig. 4.

In Fig. 4, the students can accurately shade the regions determined in the question. Then with the help of fraction bars, the students summed these regions and put their answers in the answer section.

In the next problem, students were asked to calculate the fractions using the number line. Number line had been drawn in the answer section; the students would only need to determine the right point of the distance reached by the athlete. The distance set by the students would eventually still be summed using the number line.

In this problem, the students had to add up the distances of two athletes who were swimming. The students determined the distance of the first athlete on the number line, and then summed with the second athlete's distance. Thus, the students could draw the conclusion that the sum of both athletes can be seen from the number line drawn by the students. The students' answers are shown in Fig. 5.
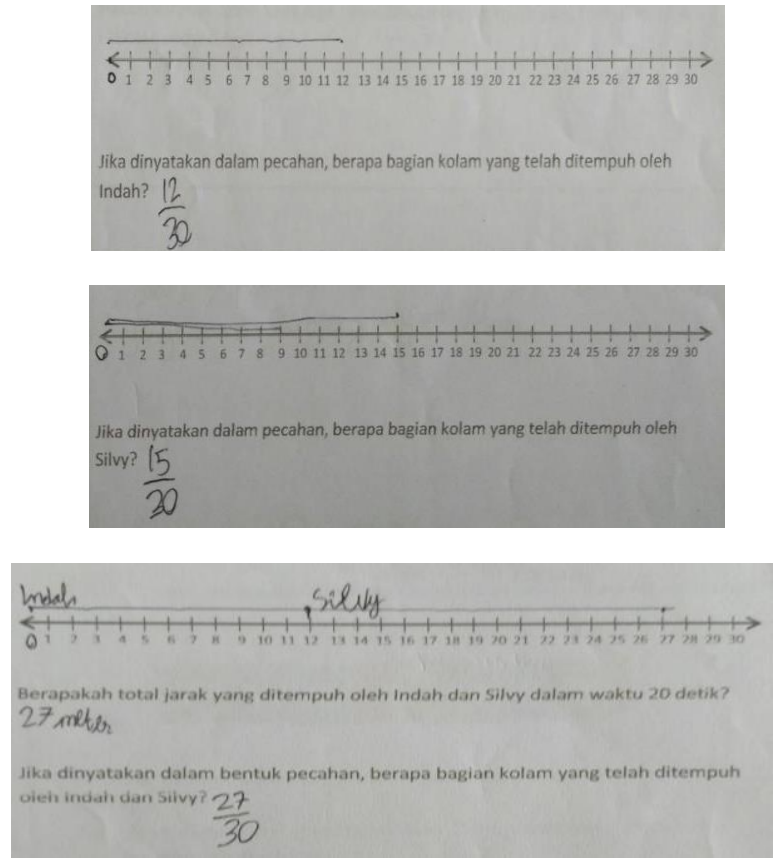

Fig. 5. Students' answer on the activity $2 \mathrm{~b}$ using number line

The students could correctly determine the point that represented the distance of the athlete. The students' answers illustrated that the students have understood how to add up fractions with common denominators using the number line.

\section{Activity 3. Addition of fractions with different denominators}

The students were instructed to solve a problem where swimmers from Japan and Korea reached certain distances in certain seconds, and the two distances were summed. In this activity, the students were asked to use the fraction bar in the process of finding the sum of fractions. The use of fraction bar on the activity was equivalent to the fraction bar on activity 2 . The students were given fraction bar with different sections, and each student shaded fraction bar in accordance with a predetermined section. The students cut one fraction bar, pasted it to a fraction bar intact, and calculated the number of the existing sections in the fraction bar. Student activity can be seen in Figure 6.

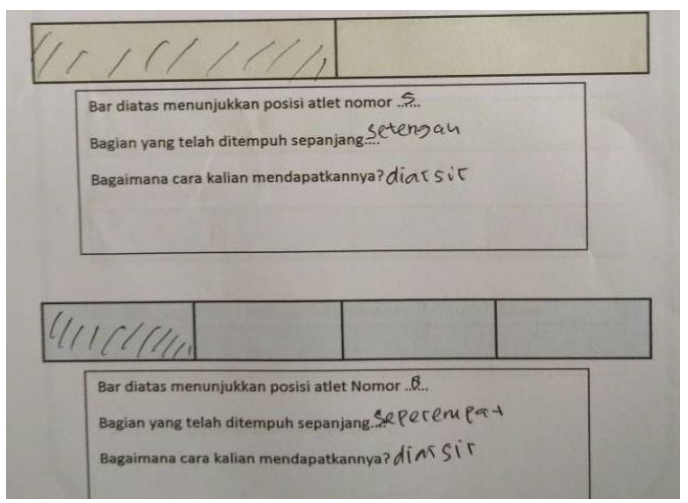

(a)

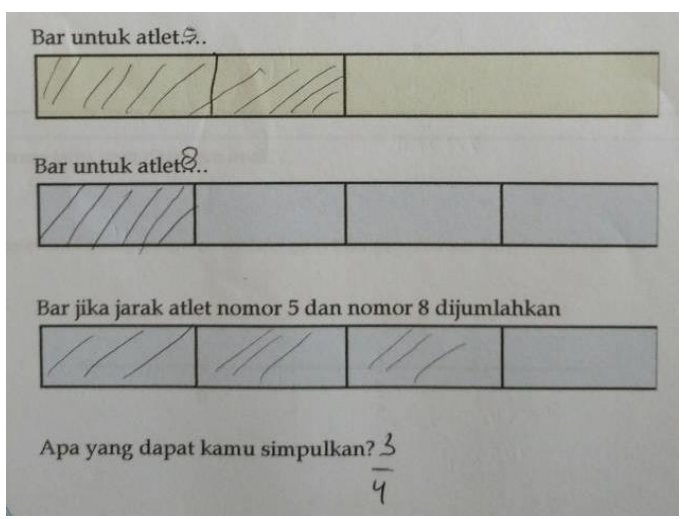

(b)

Fig. 6. Students' answer on the activity 3 a using fraction bar

In Figure 6, the students were correct in adding fractions with different denominators. The students added the two fractions with the given bar. They put their solutions onto the provided activity sheet. This is in line with the hypothetical learning trajectory designed by the researcher.

In the next activity, the students solved different problems but still in similar context, namely swimming pool. The students were asked to add the distances of both athletes. The distances of the two athletes were determined by the part of the reached swimming pools. However, in this case, the length of the pools used different denominators. Afterward, the students were asked to solve the question using the number line. The results of the students' answers are shown in Fig. 7. 


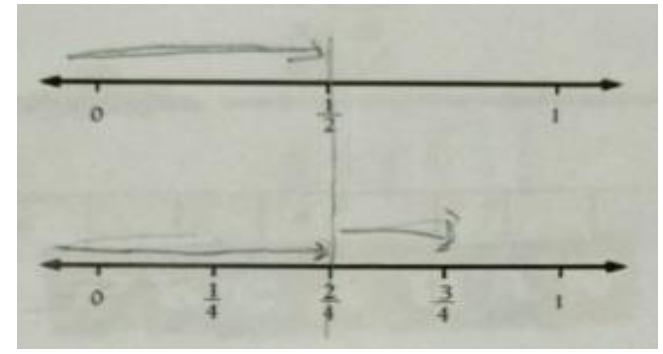

Fig. 7. The students' answer on activity $3 \mathrm{~b}$ using number line

Fig. 7 shows the students adding fractions using number line accurately. They have to know that the sum of fractions with different denominators cannot be done directly, but they must equalize the denominator first.

From the results of the research conducts on the fractions material using PMRI approach, PMRI approach is considered very good to be applied in either the fractions material or other materials. By the support of context and learning media, students learn more enthusiastically. In addition, PMRI approach can make the students more active in learning process. Moreover, the students do not simply do calculation, but they also understand the answer from the problems.

\section{CONCLUSSION}

Learning trajectory obtained is in the form of the trajectories of the learning process which is through by students start from the activities of knowing and understanding the meaning of fractions, shading the fractions bar, completing the fractions addition using fraction bar and the number line, Activities in the students' worksheets which have been designed to help students understand and resolve problems of the fractions addition from its intuitive informally to the problem-solving formally.

\section{ACKNOWLEDGMENT}

The authors would like to thank for $5^{\text {th }}$ SEA-DR that has given authors the opportunity to present the results of this study. Then, authors expressed acknowledgement to DIKTIIndonesian Directorate General of Higher Education that has funded this research.

\section{REFERENCES}

[1] Ullya, Zulkardi and R. I. Putri, "Desain bahan ajar penjumlahan pecahan berbasis pendidikan matematika realistik (PMRI) untuk siswa kelas IV Sekolah Dasar Negeri 23 Indralaya," Jurnal Pendidikan Matematika, vol. 4, no. 2, pp. 86-89, 2010.

[2] E. A. Sari, D. Juniati and S. M. Patahudin, "Early fractions learning of 3rd grade students in SD Laboratorium Unesa," Journal on Mathematics Educations, vol. 3, no. 1, pp. 17-28, 2012.

[3] S. Baxter and C. Gray, "The application of student-centered learning approaches to clinical education," International Journal Of Language\&Communication Disorder/Royal Collage of Speech\&Language Therapist, vol. 36, pp. 396-400, 2001.

[4] C. C. Chase and K. M. Geldenhuys, "Student centered teaching in a large heteregeneous class," Medical Education, vol. 35, no. 11, p. 1071, 2001.
[5] A. In'am and S. Hajar, "Learning geometry through discovery learning using a scientific approach," International Journal of Instruction, vol. 10, no. 1, pp. 55-70, 2017.

[6] M. S. Gunawan, R. I. Putri and Zulkardi, "The Swimming Context to Assit Student Understand Addition of Fractions," in International Education Postgraduate Seminar, Johor Baru, Malaysia, 2017.

[7] P. Cobb and E. Yackel, "Constructivist, emergent, and sociocultural perspective in the context of developmental research," Educational Psychologist, vol. 31, no. 3/4, pp. 175-190, 1996.

[8] R. I. Putri, M. Dolk and Zulkardi, "Professional development of PMRI teachers for introducing social norms," IndoMs-JME, vol. 6, pp. 1-15, 2015.

[9] M. Van den Heuvel-Panhuizen, "The didactical use of models in realistic mathematics education; an example from a longitudinal trajectory on percentage," Educational Studies in Mathematics, vol. 54, pp. 9-35, 2003.

[10] Zulkardi, "Developing a Learning Environment on Realistic Mathematics Education For Indonesian Student Teachers," Ph.D Thesis University of Twente, Enschede, the Netherlands, 2002.

[11] R. I. Putri, "Evaluasi Program Pelatihan Pendidikan Matematika Realistik Indonesia (PMRI) bagi Guru Matematikan Sumatera Selatan," in Seminar Nasional Implementasi Kurikulum 2013, Palembang, 2013.

[12] J. d. Lange, "Freudental Institute," in 9th International Congress on Mathematics Education (ICME9), Japan, 2000.

[13] J. A. Van de Walle, K. S. Karp and J. M. Bay Williams, Elementary and Middle School Mathematics Teaching Developmentally (Eight Ed), United States of America: Pearson Educations, 2013.

[14] L. Khuriyati, Y. Hartono and Somakim, "Desain pembelajaran operasi pecahan menggunakan kertas berpetak di kelas IV," Jurnal Paradigma, vol. 8, no. 3, pp. 62-69, 2015.

[15] M. Zabeta, Y. Hartono and R. I. Putri, "Desain pembelajaran materi pecahan menggunakan pendekatan PMRI," Beta Jurnal Pendidikan Matematika, vol. 3, no. 1, pp. 98-112, 2015.

[16] K. Gravemeijer and D. Van Eerde, "Design research as a means for building a knowledge base for teachers and teaching in mathematics education," The Elementary School Journal, vol. 109, 2009.

[17] A. Bakker, "Design Research on How IT May Support The Develpoment of Symbols and Meaning in Mathematics Education," Freudenthal Institute, Utrecht University, Netherlands, 2003.

[18] K. Gravemeijer and P. Cobb, "Design Research From The Learning Design Perspective," in Eduational Design Research, London, Routledge, 2006.

[19] Bustang, Zulkardi, Darmawijoyo, M. Dolk and D. Van Eerde, "Developing a local instructional theory for learning the concept of angle through visual field activities and spatial representations," International Education Studies, vol. 6, no. 8, pp. 58-70, 2013.

[20] D. A. Risma, R. I. Putri and Y. Hartono, "On developing students' spatial visualization ability," International Education Studies, vol. 6, no. 9, pp. 1-12, 2013.

[21] Zulkardi and R. I. Putri, "Mendesain Sendiri Soal Kontekstual Matematika," in Prosiding KNM13, Semarang, 2006. 